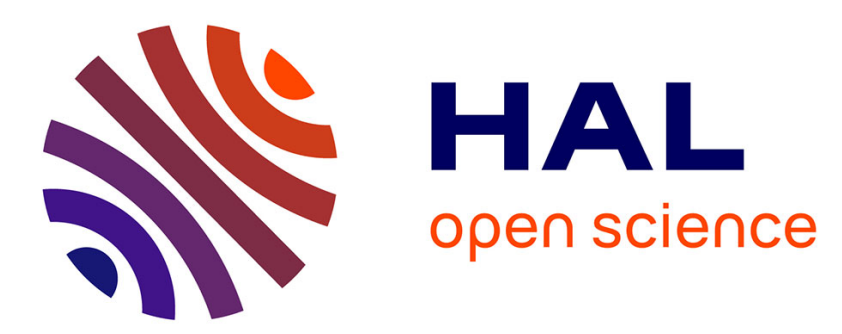

\title{
Climate and land-use change during the late Holocene at Lake Ledro (southern Alps, Italy)
}

S. Joannin, Michel Magny, Odile Peyron, B. Vannière, Didier Galop

\section{To cite this version:}

S. Joannin, Michel Magny, Odile Peyron, B. Vannière, Didier Galop. Climate and land-use change during the late Holocene at Lake Ledro (southern Alps, Italy). The Holocene, 2014, pp.1-12. 10.1177/0959683614522311. hal-01187734

\section{HAL Id: hal-01187734 \\ https://hal.science/hal-01187734}

Submitted on 27 Aug 2015

HAL is a multi-disciplinary open access archive for the deposit and dissemination of scientific research documents, whether they are published or not. The documents may come from teaching and research institutions in France or abroad, or from public or private research centers.
L'archive ouverte pluridisciplinaire HAL, est destinée au dépôt et à la diffusion de documents scientifiques de niveau recherche, publiés ou non, émanant des établissements d'enseignement et de recherche français ou étrangers, des laboratoires publics ou privés. 


\title{
Climate and land-use change during the late Holocene at Lake Ledro (southern Alps, Italy)
}

\author{
Sébastien Joannin, 1,2,3,4 Michel Magny, ${ }^{1,2}$ Odile Peyron, 2,5 Boris \\ Vannière $^{1,2}$ and Didier Galop ${ }^{6}$
}

\begin{abstract}
This paper investigates the relative influences of climatic and anthropogenic factors in explaining environmental and societal changes in the southern Alps, Italy. We investigate a deep sediment core (LL08I) from Lake Ledro (652 m a.s.l.). Environmental changes are reconstructed through multiproxy analysis, that is, pollen-based vegetation and climate reconstruction, magnetic susceptibility (MS), lake level, and flood frequency, and the paper focuses on the climate and land-use changes which occurred during the late Holocene. For this time interval, Lake Ledro records high mean water table, increasing amount of pollen-based precipitation, and more erosive conditions. Therefore, while a more humid late Holocene in the southern Alps has the potential to reinforce the forest presence, pollen evidence suggests that anthropogenic activities changed the impact of this regional scenario. Land-use activity (forest clearance for pastoralism, farming, and arboriculture) opened up the large vegetated slopes in the catchment of Lake Ledro, which in turn magnified the erosion related to the change in the precipitation pattern. The record of an almost continuous human occupation for the last $4 \mathrm{I} 00$ cal. BP is divided into several land-use phases. On the one hand, forest redevelopments on abandoned or less cultivated areas appear to be climatically induced as they occurred in relation with well-known events such as the 2.8-kyr cold event and the 'Little Ice Age'. On the other hand, climatically independent changes in land use or habitat modes are observed, such as the late-Bronze-Age lake-dwellings abandonment, the human population migration at $c$. I600 cal. BP, and the period of the Black Death and famines at $600 \mathrm{cal}$. BP.
\end{abstract}

\section{Keywords}

climate oscillations, land-use, late Holocene, soil erosion, southern Alps, vegetation dynamic

Received 8 January 2014; revised manuscript accepted 10 January 2014

\section{Introduction}

Past environmental changes are central to understanding the relationship between human society and climate changes. Globalscale vegetation landscape modeled by Foley et al. (2005) shows a step-by-step increase in human impact from natural ecosystems, clearing of woodlands and then extensive and intensive agriculture. Some authors argue in favor of the role of summer or winter temperature in driving the vegetation growth, in particular in mountainous area (e.g. Davis et al., 2003; Kleinen et al., 2011).

Paleoecological data are needed when attempting to accurately reconstruct paleoenvironment and their forcing factor beyond the last two millennia (e.g. Dearing, 2006). Recent palynological records have pointed out how crucial it is to disentangle human and climate influences for the late Holocene in the Alps (e.g. Tinner et al., 2003; Valsecchi et al., 2010). Here, precipitation regimes are more variable than temperature (e.g. Wirth et al., 2013), and this certainly affected vegetation and human activities. In the southeast of the Alps and in the Po Plain, changing human population pressures are recorded (e.g. Magny et al., 2009a; Terramara civilization: Cremaschi et al., 2006; Mercuri et al., 2006) during the late Holocene. This questions possible climate determinism for human societies and/or human-induced environmental changes (on a wider than local scale) which are expected to enhance regional climate impact (e.g. Jalut et al., 2009; Tinner et al., 2009).
To address this question, pollen analyses can provide direct and/or indirect evidence of anthropogenic activities (e.g. Joannin et al., 2012, 2014; Mercuri et al., 2010). Moreover, paleovegetation records can be combined with nearby archaeological remains to gain clearer information. The study by Beug (1964) identified the Lake Ledro sediment sequence as a good example since it recorded both vegetation changes in close association with Bronze-Age lake-dwellings.

Recently, a well-dated and high-resolution record provided by the deep core LL081 from Lake Ledro (southern Alps, Italy; Figure 1) has been the object of intensive studies: early-middle Holocene vegetation changes (Joannin et al., 2013), pollen-based

'CNRS USR 3 I 24 MSHE Ledoux, France

2Université de Franche-Comté, France

${ }^{3}$ Université Lyon I, France

${ }^{4}$ The University of Manchester, UK

${ }^{5}$ Université Montpellier 2, France

${ }^{6}$ CNRS UMR 5602, GEODE, France

\section{Corresponding author:}

Sébastien Joannin, School of Environment and Development, University of Manchester, Oxford Road, Manchester MI3 9PL, UK.

Email: sebastien.joannin@manchester.ac.uk 


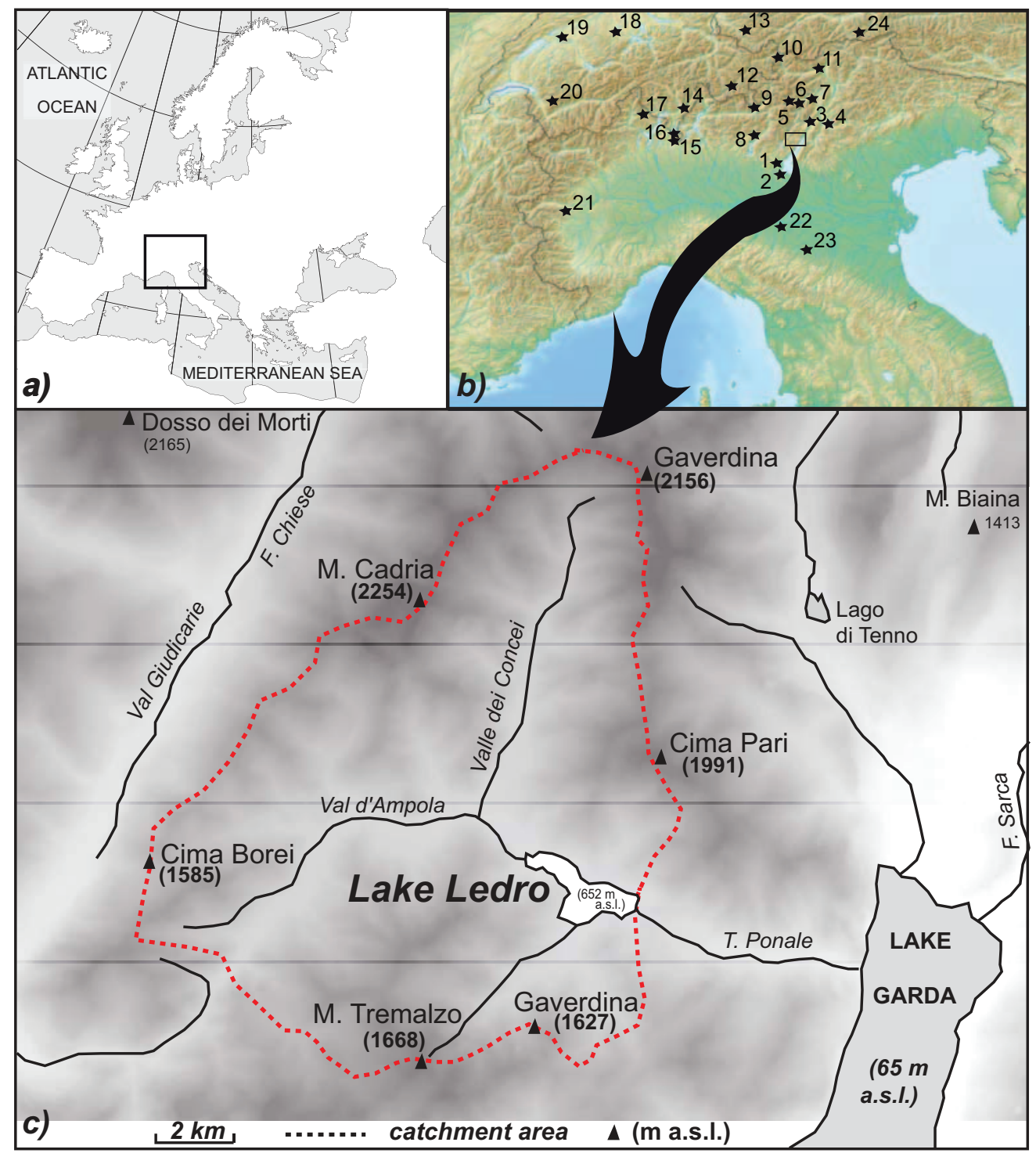

Figure I. (a) The study site in the Northern Mediterranean area; (b) location of pollen sites discussed in the paper for the Alps and Northern Italy (I: Lake Lucone (Valsecchi et al., 2006), 2: Lake Lavagnone (De Marinis et al., 2005), 3: Fiavé-Carera (Marzatico, 2007), 4: Lake Lavarone (Filippi et al., 2007), 5:Valle di Sol (Favilli et al., 20 I0), 6: Lago Nero di Cornisello (Filippi et al., 2005), 7: Lake Tovel (Gottardini et al., 2004), 8: Valcamonica (Nash, 20I2), 9: Pian di Gembro (Pini, 2002), I0: Ötztal Alps (Festi et al., in press), I I:Totenmoss (Heiss et al., 2005), I2: Lej da San Murezzan (Gobet et al., 2003), I3: Montafon Valley (Röpke and Krause, 20I3), I4:Val Febbraro (Moe et al., 2007), I5: Lago di Muzzano (Tinner et al., 2003), 16: Lago di Origlio (Tinner et al., 2003), I7: Piano and Segna (Valsecchi and Tinner, 2010), I8: Soppensee (Tinner et al., 2003), 19: Lobsigensee (Tinner et al., 2003); 20: Lauenensee (Rey et al., 20 I3), 21 : Lago Piccolo di Avigliana (Finsinger and Tinner, 2006), 22:Terramara di Santa Rosa di Poviglio (Cremaschi et al., 2006), 23:Terramara di Montale (Mercuri et al., 2006), and 24: Spannagel Cave (Mangini et al., 2005)); and (c) catchment area of Lake Ledro (dotted line).

climate reconstruction (Peyron et al., 2013), watershed soil dynamics (Simonneau et al., 2013), Holocene flood frequency calendar (Vannière et al., 2013), and flood seasonality analyses for last two millennia (Wirth et al., 2013). Additionally, vegetation and lake-level analyses have been obtained from littoral cores (Magny et al., 2009a, 2012, 2013). In this study, we investigate pollen-inferred vegetation changes for the late Holocene (i.e. since $4100 \mathrm{cal}$. BP) and compare these with the various other proxy data described above. This helps to provide a climatic and anthropogenic scenario in the Ledro's catchment in order to assess whether the environment responded to millennial and centennial scale climate changes and/or to land-use dynamics.

\section{Study area and methods}

Lago di Ledro $\left(45^{\circ} 52^{\prime} \mathrm{N}, 10^{\circ} 45^{\prime} \mathrm{E}, 652 \mathrm{~m}\right.$ a.s.1.; $\left.3.7 \mathrm{~km}^{2}\right)$ is located in Northern Italy (Figure 1a), on the southern slope of the Alps (Figure 1b). The maximum lake depth is $46 \mathrm{~m}$. The catchment area covers $111 \mathrm{~km}^{2}$ and includes mountains ranging from 1500 to $2250 \mathrm{~m}$ (Figure 1c). Some morainic tongues and calcareous and siliceous conglomeratic deposits fill the bottom of valleys. The lake was formed thanks to a morainic dam (Beug, 1964), which is now cut by the river outlet.

The climate of the Trentino region is temperate-cold, characterized by a pluviometric regime between 1000 and $1500 \mathrm{~mm} / \mathrm{yr}$, with a main peak in spring (May-June) and a secondary peak in autumn (October-November), although high precipitations also occur in the period between the two peaks. The absolute precipitation minimum occurs in winter. At Molina di Ledro, a village at the Lake Ledro outlet, the mean temperature is $9.5^{\circ} \mathrm{C}$, and the mean temperatures of the coldest and warmest months are -1 and $19.4^{\circ} \mathrm{C}$, respectively. The annual precipitation ranges from c. 750 to $c .1000 \mathrm{~mm}$ with a mean at $820 \mathrm{~mm}$ (source: http://en.climatedata.org/location/192835/).

The natural woodland of Ledro Valley shows an altitudinal zonation from broad-leaved to conifers (Soane et al., 2012). The 
lake altitude is at the limit between the upper and lower montane zones (Egli et al., 2008). The upper montane zone extends from 700-900 m to 1100-1400 m, where a mixed forest develops dominated by beech (Fagus). The subalpine zone, which develops up to $1800-2100 \mathrm{~m}$, is dominated by the coniferous forest of larch (Larix), spruce (Picea), and pine (Pinus mugo). It is replaced by the alpine zone of grasslands above $2000 \mathrm{~m}$. Around the lake, the mild climate favored the development of a mixed oak forest with lime (Tilia) and elm (Ulmus) trees, with pines (Pinus sylvestris) developing on the southward-oriented rocky slopes. At low altitude, the lower montane zone, dominated by the deciduous forest, extends from 300 to $500 \mathrm{~m}$. On the lower slopes, the Mediterranean vegetation develops, mainly Quercus ilex, Ericaceae, and olive (Olea) trees. The last taxon can reach $300 \mathrm{~m}$ as a grove forms.

A large number of pile-dwellings were found at Molina di Ledro in 1929 and 1937. R Battaglia recorded the presence of more than 10,000 piles on $4500 \mathrm{~m}^{2}$. Menotti (2004) questions the possibility to use the stratigraphical findings of Ledro as a basis of reference in distinguishing the phases in the Bronze Age (reliable data set according to Carancini and Peroni (1999) or problematic regarding the definition of the Bronze-Age phases in Northern Italy (De Marinis, 1999)). Contrary to Lake Lavagnone, where all sites of pile-dwelling are studied (De Marinis et al., 2005), Lake Ledro data set is only based on one pile-dwelling site. Botanical identifications of the wood used for the piles mainly indicate the use of larch (Larix sp. Miller), fir (Abies alba Miller), oak (Quercus sp. L.), spruce (Picea excelsa (Lam) Link), pine (P. sylvestris L.), yew (Taxus baccata L.), and Castagno (Castanea sativa Miller; Battaglia, 1943; Pinton and Carrara, 2007). Botanical identifications of daily life tools (e.g. bowls, cups, spindles, sickles) provide fir (A. alba Miller), beech, (Fagus sylvatica L.), yew (T. baccata L.), spruce (Picea abies Karst.), larch (Larix sp.), maple (Acer sp.), oak (Quercus sp. deciduous gr.), ash (Fraxinus sp.), pine (P. sylvestris/montana gr.), alder (Alnus sp.), and dogwood (Cornus sp.; Coccolini, 2006).

\section{Core sampling}

Coring site LL081 was selected in the deep basin, in a relatively distal position from the two main deltas formed by lake tributaries and approximately $1 \mathrm{~km}$ away from the lake-dwellings (Figure 2). Coring operations and retrieving are described in Joannin et al. (2013) and Vannière et al. (2013). The core sections were logged with a GEOTEK Multi Sensor Core Logger to obtain geophysical measurements (gamma-ray wet bulk density, magnetic susceptibility (MS), p-wave velocity) at $5 \mathrm{~mm}$ intervals. The master core (MC), that is, the ideal and complete lithological succession using both parallel and overlapping cores, was established based on lithological changes (with observation of key reference horizons) in combination with MS and gamma-density profiles.

\section{Radiocarbon dating}

The mid- and late-Holocene chronology is based on seven accelerator mass spectrometry (AMS) ${ }^{14} \mathrm{C}$ ages measured on terrestrial organic material from LL081 core (Table 1). Three ${ }^{14} \mathrm{C}$ ages measured on a different core (LL082; Figure 2) are included according to lithological correlation (Vannière et al., 2013). Macrofossils were collected from sediment samples sieved with a $100-\mu \mathrm{m}$ mesh screen. Radiocarbon ages were calibrated in years cal. BP by the Calib 6.0 software using the calibration curve IntCal09 (Reimer et al., 2009). Dates are expressed as intercepts with $2 \sigma$ ranges. The age-depth model is constructed using a smooth, cubic spline model (Figure 3) available within the 'Clam' software from Blaauw (2010).

\section{Pollen analyses}

Samples of $1 \mathrm{~cm}^{3}$ of sediments were treated chemically ( $\mathrm{HCl}$, $\mathrm{KOH}, \mathrm{HF}$, acetolysis) and physically (sieving) following standard procedures (Moore et al., 1991). Lycopodium tablets were added for estimating pollen concentrations $\left(\mathrm{grains} / \mathrm{cm}^{3}\right)$. Samples were taken with $5 \mathrm{~cm}$ resolution. A total of 72 pollen samples were

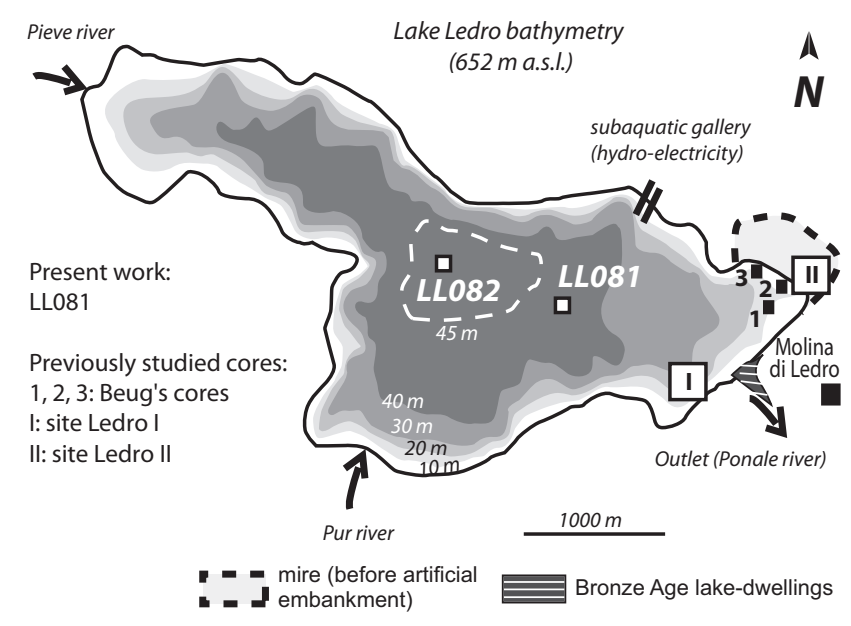

Figure 2. Lake Ledro bathymetry, location of LL08I (this study; Joannin et al., 2013) and LL082 (Vannière et al., 2013) deep sediment cores, and of littoral studied sites from Beug (1964) and Magny et al. (2009a, 2012).

Table I. AMS-radiocarbon dates with $2 \sigma$ range of calibration from Ledro's lake LL08I core.

\begin{tabular}{|c|c|c|c|c|c|}
\hline Sample ID & Laboratory code & Material & AMS ${ }^{14} \mathrm{C}$ age $\mathrm{BP}$ & Depth $M C(\mathrm{~cm})$ & Cal. yr BP $(2 \sigma)$ \\
\hline $\mathrm{P} 2-30^{\mathrm{a}}$ & POZ-27888 & Wood-charcoal & $255 \pm 30$ & 16.5 & $0-430$ \\
\hline PIb-I7 & POZ-302I6 & Wood-charcoal & $290 \pm 30$ & 82.2 & $280-460$ \\
\hline PIb-77 & POZ-302I 8 & Wood-charcoal & $1020 \pm 30$ & 142.2 & $800-1050$ \\
\hline A2a-68 & POZ-30219 & Wood-charcoal & $1445 \pm 30$ & 193.8 & $1290-1390$ \\
\hline $\mathrm{A} 2 \mathrm{a}-84.5^{\mathrm{b}}$ & ETH-39232 & Leaf remains & $1765 \pm 35$ & 210.5 & $1560-1810$ \\
\hline$A 2 a-113$ & POZ-30220 & Wood-charcoal & $1945 \pm 30$ & 238.8 & $1820-1970$ \\
\hline A3a-36 & POZ-3022I & Wood-charcoal & $2520 \pm 35$ & 298.8 & $2480-2740$ \\
\hline A3a-65b & ETH-404IO & Leaf remains & $2890 \pm 50$ & 328.1 & $2870-3210$ \\
\hline B2a-2I & POZ-30222 & Wood-charcoal & $3030 \pm 35$ & 402.6 & $3080-3360$ \\
\hline B2a-43b & ETH-404II & Leaf remains & $3575 \pm 35$ & 424.9 & $3730-3980$ \\
\hline B2a-80 & POZ-2789I & Wood-charcoal & $4080 \pm 35$ & 461.6 & $4440-4810$ \\
\hline
\end{tabular}

AMS: accelerator mass spectrometry; MC: master core. 
Age

(BP)

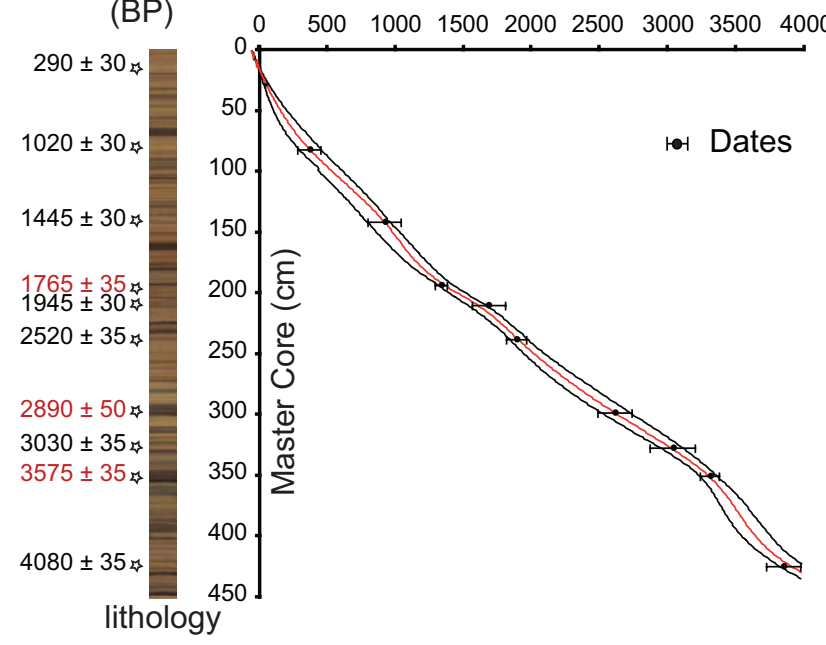

Figure 3. Lithology of MC LLO8I and age-depth model based on radiocarbon calibrated ages (AMS; see Table I) from LLO8I and LL082 (in red).

MC: master core;AMS: accelerator mass spectrometry.

analyzed under a light microscope at a standard magnification of $400 \times$. A total of 116 pollen types were identified using photo atlases (Beug, 2004; Reille, 1992-1998) and the reference collection at University of Franche-Comté.

As the dominant taxon can reduce the statistical significance of the other taxa counted, we constantly counted a minimum of 300 terrestrial pollen grains, excluding the most dominant terrestrial taxon as well as water and wetland plants, and pteridophyte spores. Along the vegetation history of this study, the dominant taxon is alternatively Fagus, Pinus, and Corylus. During the calculation process, terrestrial pollen percentages were calculated based on the sum of terrestrial pollen, which is in average 410 grains per sample. Spores and algae were added to the total pollen sum to calculate their percentage.

Using the Tilia 1.12 program (Grimm, 1992-2005), main pollen percentages are represented in Figure 4. Local pollen assemblage zones (LPAZs) were defined using the constrained incremental sum of squares (CONISS) function of Tilia 1.12 (Table 2). One solid and seven dashed lines define the limits between statistical first- and second-order splits. Figure 5 presents a pollen diagram in percentage and concentration for selected major arboreal and non-arboreal taxa. Two ratios of arboreal pollen/non-arboreal pollen (AP/NAP) were established: total arboreal taxa $\left(\mathrm{AP}_{\mathrm{t}}\right)$ and $\mathrm{AP}$ without Pinus-Castanea-Juglans $\left(\mathrm{AP}_{\mathrm{wpcj}}\right)$. The second ratio is expected to give a better understanding of changes in the uncultivated forest cover, as the pollen grain Pinus is over-represented in the pollen record, and because Castanea and Juglans have been intensively exploited since the pre-Roman times in the Italian peninsula (Mercuri et al., 2013). Olea is not included in the cultivated trees as pollen grains of this taxon are not from the catchment of the lake. Anthropogenic taxa are mainly Plantago lanceolata, Rumex, Urticaceae, and Cannabaceae.

\section{Results}

\section{Chronology}

The age-depth curve (Figure 3) shows a rather regular sedimentation rate since $c .4100 \mathrm{cal}$. yr $\mathrm{BP}$, which then accelerated during the last millennium. Thus, the pollen grain concentration follows this pattern by diminishing values since $c .1000$ cal. BP (Figure 5). The average temporal resolution during the late Holocene is estimated to be $56 \mathrm{yr} / \mathrm{sample}$.

\section{Pollen-based vegetation record}

The late-Holocene vegetation history of Lake Ledro is subdivided into five LPAZs (Table 2 and Figure 4) with lower level subdivisions. Numbering of LPAZ ranges from 7 to 11 , as it follows the pollen zones 1-6 (not shown here) corresponding to the early- to mid-Holocene period, which have been extensively published in a previous study (Joannin et al., 2013).

The zone LL-7 (c. 3950-c. 2650 cal. BP) is characterized by the mixed oak forest, inherited from the mid-Holocene (zone LL-6; Joannin et al., 2013). A major change is observed during zone LL-7, dated to this pollen zone of the Sub-Boreal, as the forest cover is reducing while Poaceae and anthropogenic taxa (mainly P. lanceolata, Rumex, Linum, Urticaceae, and Cannabaceae) develop. More specifically, we can find the roots of this reduction of the forest in the last samples from uppermost part of zone LL-6 (since c. 4100 cal. BP). In zone LL-7, two subzones are distinguished: the forest clearance that starts in LL-7a accelerates during LL-7b. First record of Castanea is attested.

The zone LL-8 (c. 2650-c. 2400 cal. BP) shows a brief return toward a more forested area. Anthropogenic indicators and herbs become scarce, while cereals are still recorded. This afforestation is mainly due to pine expansion.

The Sub-Atlantic pollen zone corresponds to LL-8 and LL-9 (c. 2400-c. 850 cal. BP). During LL-9, a new forest clearance occurs, with intervening taxa replacement highlighted by the CONISS clustering method, which identifies three subzones (Table 2). The first (LL-9a; c. 2400-c. 2050 cal. BP) is characterized by a forest clearance that mainly affected the pine forest. In subzone LL-9b (c. 2050-c. 1300 cal. BP), abrupt introduction of Juglans and regular presence of Castanea are observed. Picea and Abies developed during the second part (1700-1350 cal. BP) of subzone LL-9b. Anthropogenic taxa, as well as cereals, rather disappeared from the pollen assemblage during this interval characterized by a new afforestation. Then, a new, major forest reduction initiates in the subzone LL-9c (c. 1300-c. 850 cal. BP), which does not affect Fagus. AP $_{\text {wpcj }}$ decreased of about $29 \%$ in c. 450 years. It is marked by a clear and strong human impact that is corroborated by high amount of Juglans (up to $12 \%$ at c. 900 cal. $\mathrm{BP}$ ), increases of Poaceae and anthropogenic indicators, and steady cereal percentage.

Zone LL-10 (c. 850-c. 70 cal. BP) is characterized by low rates of $\mathrm{AP}_{\text {wpcj. }}$ Two subzones are distinguished. In subzone LL10a (up to c. 550 cal. BP), deciduous Quercus and Fagus decreased, while Fraxinus ornus, Ericaceae, Ostrya, and Mediterranean plants such as Olea and Phillyrea developed. Up to $c .70$ cal. BP, all taxa related to agriculture, arboriculture, and to anthropogenic activities such as pastoralism increased (i.e. mainly $P$. lanceolata, Rumex, and Urticaceae). Zone LL-11 shows the return toward a more forested area in the vicinity of Lake Ledro, forming a mixed forest dominated by light-demanding taxa Corylus and Carpinus.

\section{Discussion}

\section{Impact of flood events on the pollen data}

Vannière et al. (2013) identified multiple flood deposits embedded in the sediments of Lake Ledro. Therefore, impacts of flood events on the pollen concentration must be tested, as pollen grains, which are deposited in the deepest part of the lake, are mostly provided by rivers. As previously discussed by Joannin et al. (2013), two mid-Holocene thick flood deposits provide opposite variations in pollen concentration (diluting or concentrating). Smaller flood events recorded along the late Holocene do not provide a clear pattern (Figure 5). The observation could be blurred by the sampling resolution, which differs from pollen to flood analysis, and by the pollen sampling itself, which could 


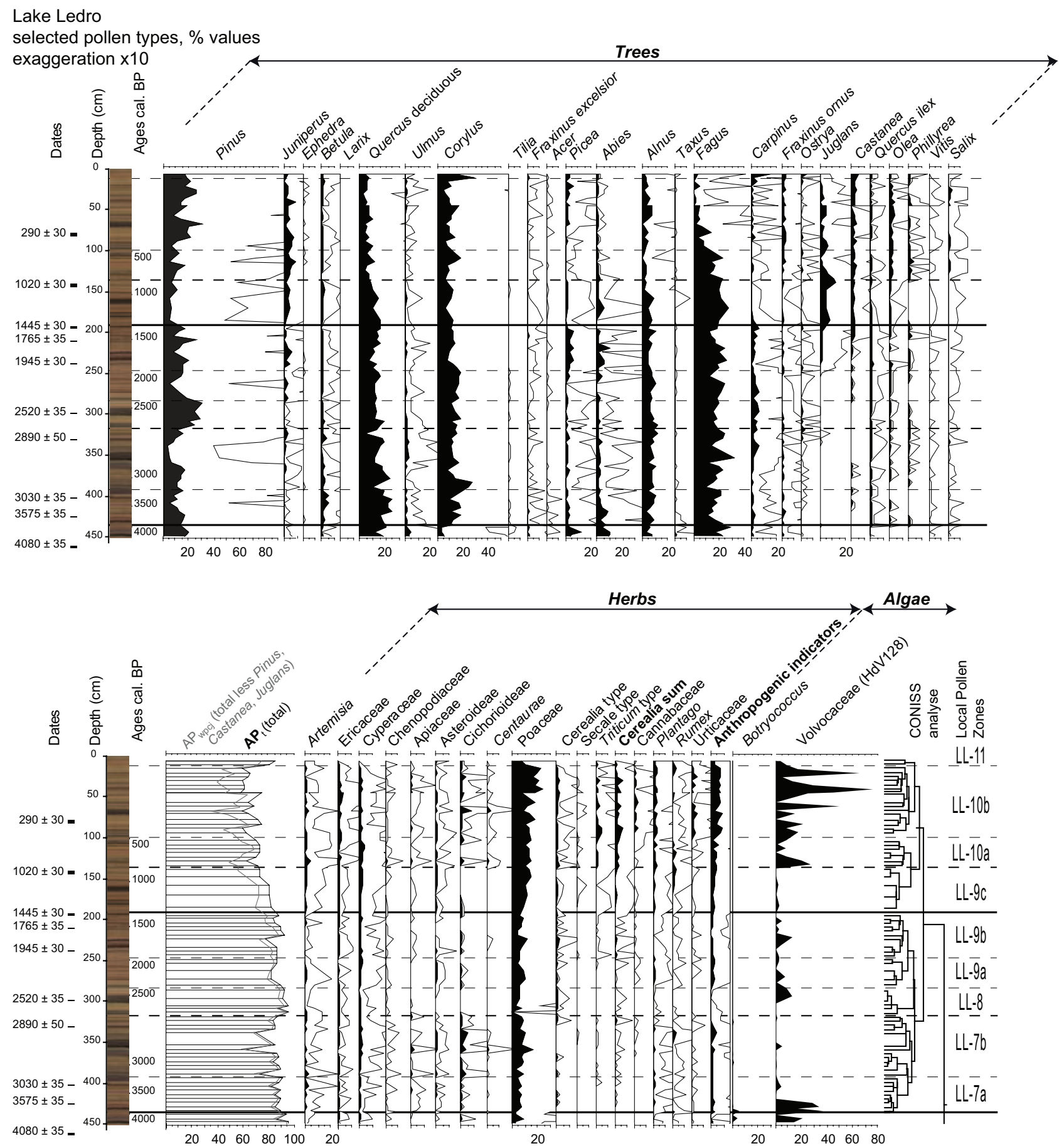

Figure 4. Pollen diagram represented in-depth showing percentages of main pollen taxa. Pollen zones, which are based on CONISS, are numbered to follow pollen zones I-6 corresponding to the early- to mid-Holocene period (Joannin et al., 20I3).

CONISS: constrained incremental sum of squares; $\mathrm{AP}_{\mathrm{t}}$ : total arboreal taxa; $\mathrm{AP}_{\text {wpci }}$ : arboreal pollen without Pinus-Castanea-Juglans.

not be exclusively done in normal deposits due to the numerous flood deposits.

\section{Growing land-use activities during the late Holocene}

The anthropogenic influence is traced using pollen grains from cultivated taxa (i.e. mainly cereal-type pollen) and from taxa indirectly favored by anthropogenic activities (e.g. Urticaceae). Moreover, one must keep in mind the anthropogenic influence stated from the early- and mid-Holocene vegetation record at Ledro provided by Joannin et al. (2013) to highlight the lateHolocene vegetation history. There, mainly cereal-type pollen grains occurred sporadically since $c .7500 \mathrm{cal}$. BP. Considering the low transportation potential of cereal-type pollen grains
(Tweddle et al., 2005), their record in the sediment therefore suggests the establishment of communities in the vicinity of the lake only (as early as the early Neolithic). At a larger scale, development of pastoral transhumance is attested in central-eastern Alps (Trentino) since the late Neolithic (Marzatico, 2009).

The interval 4100-2650 cal. BP. The forest cover reduction that runs between c. 4100 and c. 2650 cal. BP impacts preferentially the montane vegetation (Fagus, Abies, and Picea; Figure 5). While cereal record is still scarce, the pollen count attests the development of more open vegetation composed of herbs (Poaceae, Ast. Artemisia, Asteroideae, and Ast. Cichorioideae) and anthropogenic taxa (P. lanceolata, Rumex, Urticaceae, and scattered Cannabaceae). This suggests a human impact favoring 
Table 2. Inventory of local pollen zones with depth and estimated ages, main taxa, total of AP, and common and rare pollen types.

\begin{tabular}{|c|c|c|c|c|}
\hline \multirow[t]{2}{*}{ LPAZ } & Depth $(\mathrm{cm})$ & \multirow[t]{2}{*}{ Main taxa observed } & \multirow[t]{2}{*}{ Total of AP \% } & \multirow[t]{2}{*}{ CPT and RPT } \\
\hline & Age (cal. yr BP) & & & \\
\hline LL-II & $\begin{array}{l}11-0 \\
70-0\end{array}$ & $\begin{array}{l}\text { Corylus-Pinus- } \\
\text { Carpinus }\end{array}$ & $\begin{array}{l}\mathrm{AP}_{\mathrm{t}}>77 \\
\mathrm{AP}_{\mathrm{wpcj}}>68\end{array}$ & $\begin{array}{l}\text { CPT: deciduous Quercus, Picea, Alnus, Fagus, Fraxinus ornus, Ostrya, } \\
\text { Castanea, and Poaceae } \\
\text { RPT: Betula, Abies, Juglans, Olea, Salix, Cannabaceae, and Bras- } \\
\text { sicaceae }\end{array}$ \\
\hline LL-IOb & $\begin{array}{l}103-11 \\
550-70\end{array}$ & $\begin{array}{l}\text { Corylus-Pinus- } \\
\text { Poaceae }\end{array}$ & $\begin{array}{l}A P_{t} 77-58 \\
A P_{\text {wpci }} 63-43\end{array}$ & $\begin{array}{l}\text { CPT: deciduous Quercus, Alnus, Fagus, Carpinus, Ericaceae, Juglans, } \\
\text { Castanea, Olea, Juniperus, Ephedra, Apiaceae, Ast. Cichorioideae, } \\
\text { Centaurea, Triticum, Cannabaceae, Plantago lanceolata, Rumex, } \\
\text { Urticaceae, and Artemisia }\end{array}$ \\
\hline LL-IOa & $\begin{array}{l}135-103 \\
850-550\end{array}$ & & $\begin{array}{l}A P_{t} 75-72 \\
A P_{\text {wpci }} 68-55\end{array}$ & $\begin{array}{l}\text { CPT: deciduous Quercus, Pinus, Alnus, F. ornus, Juglans, Castanea, } \\
\text { Olea, Juniperus, Cyperaceae, Triticum, P. lanceolata, Rumex, Urtica- } \\
\text { ceae, and Artemisia }\end{array}$ \\
\hline LL- 10 & $\begin{array}{l}135-11 \\
850-70\end{array}$ & $\begin{array}{l}\text { Fagus-Corylus- } \\
\text { Poaceae }\end{array}$ & & $\begin{array}{l}\text { RPT: Betula, Fraxinus excelsior, Picea, Abies, Ostrya, Pistacia, Quercus } \\
\text { ilex,Vitis, Salix, Alisma, Convolvulus, Fagopyrum, Thalictrum, and } \\
\text { Lamiaceae }\end{array}$ \\
\hline LL-9c & $\begin{array}{c}190-135 \\
1300-850\end{array}$ & & $\begin{array}{l}A P_{t} 85-72 \\
A P_{w p c j} 84-55\end{array}$ & $\begin{array}{l}\text { CPT: Pinus, Picea, Abies, Alnus, Juglans, Castanea, Olea, Juniperus, } \\
\text { Cyperaceae, Poaceae Triticum, P. lanceolata, Rumex, and Urticaceae }\end{array}$ \\
\hline LL-9b & $\begin{array}{c}249-190 \\
2050-1300\end{array}$ & & $\begin{array}{l}A P_{t} 93-80 \\
A P_{\text {wpc }} 88-73\end{array}$ & $\begin{array}{l}\text { CPT: Pinus, Picea, Abies, Alnus, Carpinus, Juglans, Juniperus, Poaceae, } \\
\text { P. lanceolata, and Rumex } \\
\text { RPT in LL-9b to 9c: Betula, Fraxinus excelsior-ornus, Ericaceae, } \\
\text { Ostrya, Pistacia, Phillyrea, Q. ilex, Vitis, Salix, Ast. Asteroideae, Centau- } \\
\text { rea, Cerealia-type, Convolvulus, and Lamiaceae }\end{array}$ \\
\hline LL-9a & $\begin{array}{c}280-249 \\
2400-2050\end{array}$ & & $\begin{array}{l}A P_{t} 90-82 \\
A P_{\text {wpc }} 87-79\end{array}$ & $\begin{array}{l}\text { CPT: Pinus, Fraxinus excelsior, Picea, Abies, Alnus, Carpinus, Juniperus, } \\
\text { Poaceae, and P. lanceolata } \\
\text { RPT: Betula, Acer, Ericaceae, Ostrya, Pistacia, Cyperaceae, Ast. } \\
\text { Asteroideae, and Artemisia }\end{array}$ \\
\hline LL-9 & $\begin{array}{c}280-135 \\
2400-850\end{array}$ & $\begin{array}{l}\text { Fagus-deciduous } \\
\text { Quercus-Corylus }\end{array}$ & & \\
\hline LL-8 & $\begin{array}{c}310-280 \\
2650-2400\end{array}$ & $\begin{array}{l}\text { Fagus-deciduous } \\
\text { Quercus-Corylus }\end{array}$ & $\begin{array}{l}A P_{t} 98-79 \\
A P_{w p c j} 95-76\end{array}$ & $\begin{array}{l}\text { CPT: Pinus, Picea, Abies, Alnus, Carpinus, F. ornus, Ostrya, Juniperus, } \\
\text { Cereal tp., and Poaceae } \\
\text { RPT: Betula, Fraxinus excelsior, Acer, Q. ilex, Olea, Plantago, Cypera- } \\
\text { ceae, Thalictrum, and Rumex }\end{array}$ \\
\hline LL-7b & $\begin{array}{c}385-310 \\
3100-2650\end{array}$ & & $\begin{array}{l}A P_{t} 98-63 \\
A P_{w p c j} 95-57\end{array}$ & $\begin{array}{l}\text { CPT: Pinus, Picea, Abies, Alnus, Carpinus, F. ornus, Ostrya, Juniperus, } \\
\text { Apiaceae, Poaceae, P. lanceolata, Rumex, and Urticaceae }\end{array}$ \\
\hline LL-7a & $\begin{array}{c}435-385 \\
3950-3100\end{array}$ & & $\begin{array}{l}A P_{t} 95-73 \\
A P_{\text {wpc }} 93-68\end{array}$ & $\begin{array}{l}\text { CPT: Pinus, Betula, Fraxinus excelsior, Acer, Picea, Abies, Alnus, } \\
\text { Carpinus, F. ornus, Ostrya, Apiaceae, Poaceae, P. lanceolata, and } \\
\text { Urticaceae }\end{array}$ \\
\hline LL-7 & $\begin{array}{c}435-310 \\
3950-2650\end{array}$ & $\begin{array}{l}\text { Fagus-deciduous } \\
\text { Quercus-Corylus }\end{array}$ & & $\begin{array}{l}\text { RPT: Ulmus, Tilia, Taxus, Q. ilex, Vitis, Salix, Ast. Cichorioideae, cereal } \\
\text { tp., and Cannabaceae }\end{array}$ \\
\hline
\end{tabular}

CPT: common pollen types; RPT: rare pollen types;AP: arboreal pollen; LPAZ: local pollen assemblage zone. Note that two ratios $\mathrm{AP}_{\mathrm{t}}$ and $\mathrm{AP}_{\mathrm{wpcj}}$ are used (arboreal pollen without Pinus, Castanea, and Juglans $\left.\left(\mathrm{AP}_{\mathrm{wpcj}}\right)\right)$.

agro-pastoral activity on mid- and high-altitude meadows. The period around $4000 \mathrm{cal}$. BP is indeed considered to be the beginning of the integration of high-mountain pastures in nearby sites of southern Alps (Menotti, 2004) such as Fiavé-Carera (Marzatico, 2007), Val di Sole (Favilli et al., 2010), and Lej da San Murezzan (Gobet et al., 2003), which probably causes the decline of Abies and Picea in Lake Lavarone (Filippi et al., 2007; Figure 1). However, such an opening of the forest seems delayed in sites of high altitude such as Lago Nero di Cornisello (Filippi et al., 2005), at Totenmoss (Heiss et al., 2005) and in Ötztal Alps (Festi et al., in press).

At c. 4100 cal. BP, the forest reduction is also recorded by the pollen record from littoral core L-II of Lake Ledro (Magny et al., 2009a). This site is located close to the Bronze-Age lake settlements found at the outlet of the lake (Figure 2). Therefore, humans who occupied the lakeshore during the early to late Bronze Age were probably responsible for the landscape change in the vicinity of Lake Ledro. These Bronze-Age lake settlements developed between 4100 and $3200 \mathrm{cal}$. BP in the outlet area of Lake Ledro
(Cortesi and Leonardi, 2002; Pinton and Carrara, 2007) and elsewhere in Northern Italy (e.g. Magny et al., 2009a; Moe et al., 2007). According to Fasani (2002), development of the pile-dwellings in the Lake Garda region during the early Bronze Age (around $\mathrm{BC}$ 2050-2010) is probably associated with the arrival of new settlers from the mid-Danubian region. Two lakes well known for lakedwellings exist relatively close to Lake Ledro, however, located in lowlands around Lake Garda (Figure 1). On the basis of radiocarbon dates, shores of Lake Lucone were occupied from c. 4000 to 3100 cal. BP according to Valsecchi et al. (2006). De Marinis et al. (2005) established that Lake Lavagnone was continuously occupied during the Bronze Age. The continuous occupation of this lake is well reconstructed thanks to investigations in several sites of lake-dwellings, each revealing phases of abandonment and reoccupation. At Lucone and Lavagnone, onset and abandonment of lake-dwellings are coeval with spectacular increase and decrease in anthropogenic pollen indicators and charcoal concentration. At Ledro, the pollen record suggests an increase in the deforestation during the late Bronze Age (Figure 6). However, more 


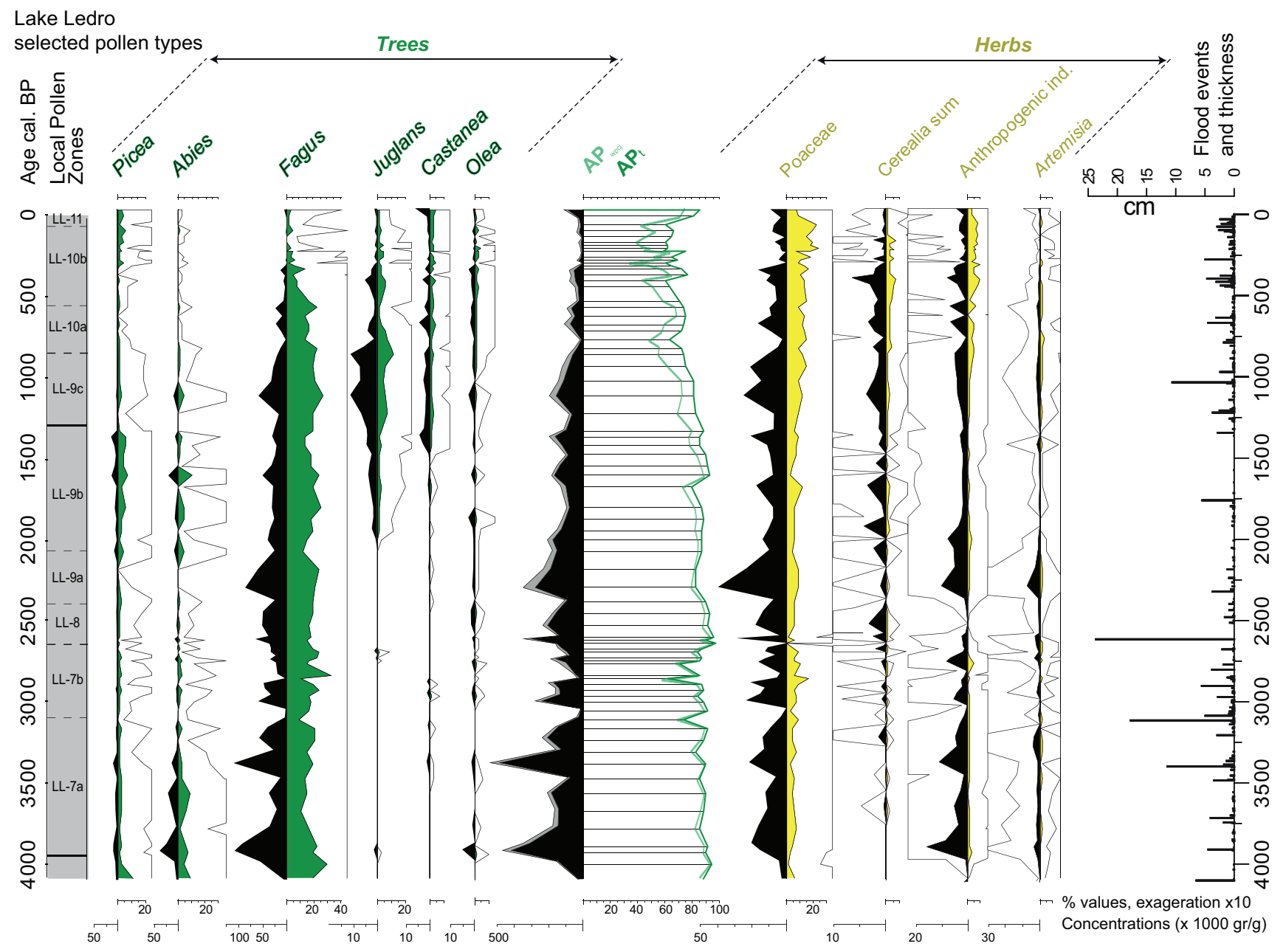

Figure 5. Selected pollen taxa represented in concentration and percentages, and flood events thickness (Vannière et al., 20I3). $A P_{t}$ : total arboreal taxa; $\mathrm{AP}_{\text {wpci }}$ arboreal pollen without Pinus-Castanea-Juglans.

archaeological investigations coupled with tree-ring/radiocarbon dating are needed at Lake Ledro to (1) better constraint the chronology of other prehistoric lake-dwellings identified around the lake and (2) better evaluate the human impact on the local/regional vegetation due to lake-dwellings and/or that due to terrestrial villages during the Bronze Age.

The interval 2650-1700 cal. BP. Pine afforestation and weak rates of anthropogenic indicators (Artemisia, Ast. Asteroideae, Ast. Cichorioideae, and Poaceae) suggest low pastoral activity from c. 2650 to $c$. $2400 \mathrm{cal}$. BP. Such a reduction echoes the pollen record at Lake Lucone (Valsecchi et al., 2006), although Ledro's record is delayed. Continued stability in cereal pollen, however, does not confirm a complete absence of human activities around Lake Ledro. Human population of the Iron Age period probably changes their land-use activities by reducing pastoralism, which therefore affects the forested area less, but ongoing crop cultivation. Marzatico (2009) reported the use of the iron sickle for haymaking is delayed to the Iron Age in the Alps.

A second phase of important human impact is attested by the forest clearance, which mostly affects the pines. This starts at $c$. $2400 \mathrm{cal}$. BP and ends at c. $1700 \mathrm{cal}$. BP. Synchronous opening is attested at Lej da San Murezzan (Gobet et al., 2003). At Ledro, cereals and anthropogenic indicators suggest the presence of cultivation crops and pastoralism. Arboriculture is attested by Olea, Juglans, and Castanea pollen types. Developments of Juglans and Castanea cultures at c. 2000 and $1500 \mathrm{cal}$. BP are delayed by approximately 500 years compared with the pollen record from
Lake Lavarone (Filippi et al., 2007). Olives were probably cultivated at lower altitude as proposed by Valsecchi et al. (2006) based on the pollen record from Lake Lucone. In lowlands of Northern Italy, Rottoli and Castiglioni (2011), who studied the plant offerings in Roman cemeteries, reported that Juglans was used at the Roman Period onset, while Castanea appears later (2nd century $\mathrm{AD}$ ).

The interval I 700-70 cal. BP. From c. $1700 \mathrm{cal}$. BP, Abies and Picea develop and participate in the new afforestation, which lasts up to $c .1300$ cal. BP. In Valcamonica, a recent archaeobotanical study at Ossimo Anvòia (850 m a.s.l.) reveals similar vegetation with beech and conifer forests, no chestnut cultivation, and parts of the area used for grazing at $c .1600 \mathrm{cal}$. BP (Allevato et al., 2013). At Ledro, this phase mostly expressed a reduction in agro-pastoralism activities. Cannabaceae cultivation also decreases while Juglans continues to be cultivated. Pollen record at Lake Ledro thus confirm the reduction of agricultural activities observed in the north and the south of the Alps (Tinner et al., 2003 and references therein).

From c. 1300 cal. BP onward, human impact strongly increases and clearly transforms the vegetation of the lake catchment area. A major opening of the forest is observed up to $c .850 \mathrm{cal}$. BP, affecting the mixed oak forest, which was replaced by pioneers and light-demanding shrubs and small trees such as Juniperus, Corylus, and Pinus. All pollen taxa associated with human activities increase (Juglans, Castanea, Olea, cereal-type, Poaceae, Ast. Asteroideae, Ast. Cichorioideae, Cannabaceae, P. lanceolata, Rumex, Urticaceae, and Artemisia). Forest clearance then 


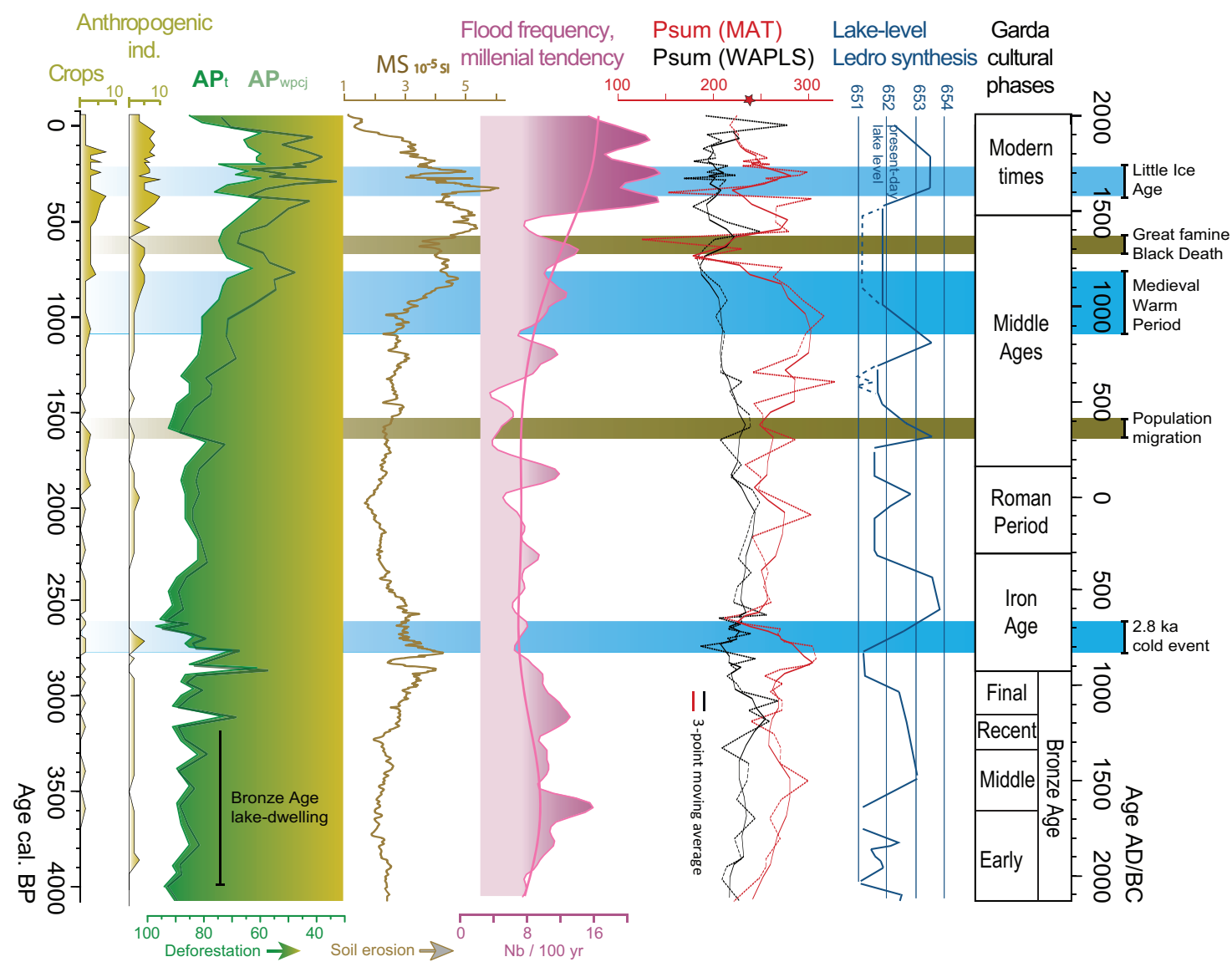

Figure 6. Ledro's record of agricultural activities, forest cover (arboreal pollen, inversed scale), erosion in the catchment (MS), flood frequency (Vannière et al., 2013), lake levels (Magny et al., 2012), and pollen-based reconstructed summer precipitation (the star indicates the present-day summer precipitation; Peyron et al., 2013). Climatically and non-climatically induced vegetation and land-use changes are shown in blue and brown, respectively.

MS: magnetic susceptibility; MAT: modern analogs technique;WAPLS: weighted averaging partial least squares.

increased up to the 19th century. This is associated with the beech forest reduction, which accelerates since $c .700$ cal. BP. Increasing human activity is described by historical data since the Medieval Period (Nequirito, 2002). Similar age for human-induced Fagus collapse is found in Piano and Segna (Valsecchi et al., 2010). Two short periods of afforestation and slight decrease in human activities are observed at c. 700-600 and c. 400-250 cal. BP. The light-demanding hazel tree is the main taxon developing during these two periods.

\section{Deciphering respective climate and human impacts in the vicinity of Lake Ledro}

In order to draw past environmental changes in the Ledro catchment and to decipher the respective influences of regional climate and of human activities, all proxies being retrieved from the Lake Ledro sediments (i.e. vegetation-based landscape, MS, flood frequency, pollen-based summer precipitation, and lake levels) are shown in Figure 6. Lake level and flood frequency are expected to be forced mainly by climate (i.e. summer moisture conditions; Magny et al., 2013), although the magnitude of flood events can be amplified by human impact over fragilized landscape (Magny et al., 2009a; Vannière et al., 2013).

MS is expected to indicate soil erosion in the catchment. Contrary to the flood frequency which changed during the entire Holocene (Vannière et al., 2013), MS only varied significantly during the late Holocene (Joannin et al., 2013). Therefore, this proxy is more related to human impact, which enhanced erosion of soils by deforestation and cultivation (Egli et al., 2008).
Pollen-based landscape reconstruction is affected by both climate and human impact. According to Peyron et al. (2013), pollen-based climate reconstructions can be influenced by human impacts over the vegetation since the Roman Period, but appear to show robust results when using the multi-method approach and by comparing with other proxies. Thus, we present summer precipitation reconstructed by two methods (MAT, modern analogs technique; WAPLS, weighted averaging partial least squares regression), and for more details, refer to the paper of Peyron and coauthors. Garda cultural periods are determined from Valsecchi et al. (2006), who successfully applied them to Lake Lucone and its surround, south of Lake Garda.

The Bronze Age. By comparison with early- and mid-Holocene records discussed in Joannin et al. (2013), the period from c. 4100 to $c .2650 \mathrm{cal}$. BP suggests an opening of the landscape, correlative to increase in erosion of soils and flood frequency. According to Vannière et al. (2013), flood frequency amplitude is indeed reinforced by openings in the vegetation. Thus, the landscape management, consisting in deforestation for pastoralism, probably weakens soil structure and favors higher runoff contribution to erosion. At the same time, increases in summer precipitation, inferred from pollen-based climate reconstruction and from lake level, probably added to enhance the runoff.

This observation leads us to consider that human impact over vegetation enhanced the local environmental response to climate triggering. The age around $4200-4000 \mathrm{cal}$. BP dates a major disruption to ancient civilizations in response to a severe drought at low latitude associated to the 4.2-kyr climatic event (Drysdale et al., 2006). It is interesting to observe a coinciding disruption at 
mid latitude, although in response to a moister climate (Magny et al., 2009b).

As at Lake Ledro, the phase of lake-dwellings in lowland lakes, that is, Lake Lucone and Lake Lavagnone, is coeval with increases of anthropogenic pollen indicators and charcoal concentration. According to Menotti (2004), an unprecedented demographic increase occurred during the early Bronze Age. At Ledro, the building of Bronze-Age lake-dwellings, which used Larix (larch), Abies (fir), and Picea (spruce) wood (Pinton and Carrara, 2007), probably caused the concomitant decrease in pollen-based forests of Abies and Picea. The presence of scarce Linum pollen grains appears to reflect the working of linen, which is attested by archaeological findings at Lake Ledro (Carra, 2012).

However, converse to the situation at Lake Ledro, decreases of anthropogenic pollen indicators followed the abandonment of lake-dwellings at Lake Lucone and Lake Lavagnone during the late Bronze Age. Therefore, the end of the lake-dwellings during the late Bronze Age (as suggested by the available archaeological data, i.e. Pinton and Carrara, 2007) does not allow the montane taxa to develop again around Lake Ledro because the landscape management continues to be recorded between 3200 and 2800 cal. BP. This phase of enhanced human pressure is attested by palynological evidence at Totenmoss (Heiss et al., 2005) and by archaeological findings (such as spear and bronze diadems at Ledro; Bruno, 2012) on the copper exploitation in the south-central Alps during the late and the final Bronze Age (Marzatico et al., 2010), and somehow confirmed by the rock-art found in the nearby valley of Valcamonica, which set firmly within the late Bronze Age (Nash, 2012). Such increasing impact contrasts with a decline of agricultural activities observed at c. $3100 \mathrm{cal}$. BP in Northern Alps (e.g. Tinner et al., 2003; Montafon Valley - Röpke and Krause, 2013; Schmidl et al., 2005; Lauenensee - Rey et al., 2013) and in lowlands from Northern Italy (e.g. Lake Lucone (Valsecchi et al., 2006) and the decline of Terramara culture and the depopulation of large areas in the Po Plain at $3100 \mathrm{cal}$. BP (Cremaschi et al., 2006; De Marinis, 1997; Mercuri et al., 2006, 2012, submitted; also discussed in Magny et al., 2009a)). Climate indicators from Lake Ledro such as sharp variations in AP ratio and MS values, and in flood events at 3100 and $2800 \mathrm{cal}$. BP may suggest that climate was relatively humid and unstable at that time. This is also supported by a lake-level highstand around 3100 cal. BP, and a marked rise in water table starting around $2800 \mathrm{cal}$. BP such as reconstructed from littoral sediment sequences (Figure 6). Finally, this claims for a relative emancipation of proto-historic societies from more instable climatic conditions as hypothesized by Magny et al. (2009a).

The Iron Age and Roman Period. From c. 2650 to c. 2400 cal. $\mathrm{BP}$, afforestation and lesser pastoralism are associated with indication for less erosion in MS values, which could then be related to climate deterioration and/or to low farming activities. This period corresponds to cold and wetter conditions in southern Alps (e.g. Lej da San Murezzan, Gobet et al., 2003; Val Febbraro, Moe et al., 2007), which is confirmed by a major highstand at $2600 \mathrm{cal}$. BP in Lake Ledro (Magny et al., 2012). Van Geel et al. (1996) have shown that the climate cooling at c. 2800 cal. BP was a global event, which affected various regions in both hemispheres, associated with glacier advances in the Alps (Deline and Orombelli, 2005; Ivy-Ochs et al., 2009). Climate deterioration therefore can be considered to explain this human pressure decrease.

From c. 2400 to $c .1700$ cal. BP, human activity inferred from pollen analysis and erosion markers are less important compared with what is observed for the early-middle Bronze Age. This is interpreted as indicative of soil stabilization in the catchments (Simonneau et al., 2013). Tinner et al. (2003) already discussed the link between human population growth and technical innovations that favored development of anthropogenic pollen indicators and accelerated soil erosion since the Iron Age. Such increasing impact is well recorded in the Alps such as at Pian di Gembro (Pini, 2002), at Lago Piccolo di Avigliana (Finsinger and Tinner, 2006), at Lauenensee (Rey et al., 2013), and in Ötztal Alps (Festi et al., in press). In Montafon Valley, a palynological and paleobotanical study of three peat bogs also reported an increase of human impact (Schmidl et al., 2005). However, this is less marked at Lake Ledro during the Iron Age and Roman Period. Such a difference may reflect a possible change in the gravity centers of settlement from elevated to low-altitude areas as exemplified by the French Alps (Segard, 2009). Moreover, low soil erosion at Ledro may be linked with even less human impact compared with the Bronze-Age occupation. Other records such as that from Lake Lucone also show low human activities before 2000 cal. BP (Valsecchi et al., 2006) or a decrease in the use of fire in land use as observed in Val di Sole (Favilli et al., 2010). According to Heiss et al. (2005), the pollen record from Totenmoss suggests a recovery of the forest during the Roman times.

The Middle Ages and Modern times. On a millennial-scale, during the Middle Ages and Modern times, pollen-inferred human activities and MS-inferred erosion rate suggest that land use becomes the main factor that controls both proxies. According to Vannière et al. (2013), the increase in flood frequency and highstands of the lake that prevailed until the 20th century are driven by climate. It is therefore expected that human activities have affected the sediment record of flood activity, and they can partially explain the amplitude of the increases in flood activity.

On a centennial scale, the afforestation and reduction of agricultural activities at $c .1700-1500 \mathrm{cal}$. BP occur during a phase of low flood frequency and high lake level. The change in the landscape management seems not related to a clear shift in the climate pattern, and within the dating uncertainties, can be related with the migration period, which caused a decline of human pressure in north and south of the Alps (Tinner et al., 2003 and reference therein).

A first huge increase of land-use activities and its correlative erosion increase are contemporaneous of the 'Medieval Warm Period' (MWP). Temperature reconstructed using a stalagmite from Spannagel Cave in the Central Alps indicates that maxima during the MWP (i.e. between AD 800 and 1300) are similar to the present-day values (Mangini et al., 2005). Impact of this event is attested across the Alps (e.g. Lake Tovel, Gottardini et al., 2004; Montafon Valley, Schmidl et al., 2005).

Two afforestation phases are observed at 700-600 and 400$250 \mathrm{cal}$. BP. The first phase is also recorded across the Alps (e.g. Tinner et al., 2003). This suggests a decrease of the human activity, expected to be related to the demographic drop in Europe caused by Black Death and famines (e.g. Büntgen et al., 2011). The second afforestation phase took place during the 'Little Ice Age' when temperature was $1.7^{\circ} \mathrm{C}$ lower than today in the Alps (Mangini et al., 2005). This cold event affected all Europe (Luterbacher et al., 2006). It is recorded by late-Holocene maximum ice extents in the Swiss Alps and the mountains of southern Europe, which were reached in the 17th and 19th centuries (Hughes, 2010; IvyOchs et al., 2009). These glacier advances occurred when lower summer insolation in the north hemisphere coincided with solar activity minima and several strong tropical volcanic eruptions (Wanner et al., 2008). This event may have been responsible for a decline in the human population in the region of the Lake Ledro, favoring in turn a forest extension.

Reforestation occurs during the 20th century consequently to low grassland and forest exploitation. It is characterized by the development of pioneer and light-demanding taxa (Corylus and Carpinus). Both afforestation and decreasing of soil erosion suggest a reduction of land-use activities. 


\section{Conclusion}

A deep core (LL081) from Lake Ledro provides a continuous high-resolution record of vegetation history for the late Holocene. The pollen-based vegetation and pollen-based climate reconstruction are compared with environmental changes reconstructed with independent proxies (MS, lake level, and flood frequency) in order to disentangle climate and land-use impacts in the catchment area.

During the late Holocene, Lake Ledro records a high mean water table (Magny et al., 2013), increasing amount of pollenbased precipitation (Peyron et al., 2013), and more erosive conditions (Vannière et al., 2013). Although a more humid late Holocene in the southern Alps has the potential to reinforce the forest presence, pollen-based anthropogenic activities locally change the impact of this scenario. Land-use activity (farming, arboriculture, pastoralism, and forest clearance) opens the vegetated slopes in the catchment of Lake Ledro, which in turn magnified the erosion related to the change in the precipitation pattern.

The record of an almost continuous human occupation for the last $4000 \mathrm{cal}$. BP is divided in land-use phases. Forest redevelopments on abandoned or less-cultivated areas appear to be climatically induced as they occurred in relation with well-known events such as the 2.8-kyr cold event and the 'Little Ice Age'. However, climatically independent changes in land use or in habitat modes (i.e. lake-dwellings vs. terrestrial villages) are also observed, such as the late-Bronze-Age lake-dwellings abandonment, the human population migration centered at c. $1600 \mathrm{cal}$. BP, and the period of the Black Death and famines at $600 \mathrm{cal}$. BP.

\section{Acknowledgements}

We thank PD Hughes for editing the English, and AM Mercuri and one anonymous reviewer for their thorough and precious comments that helped us to improve this manuscript. We are grateful to Julien Didier for his help in the laboratory, and David Etienne, Laurent Millet, and Damien Rius for their help with data processing.

\section{Funding}

Financial support for this study was provided by the French ANR within the project LAMA (MSHE Ledoux, Besançon, France, project ANR-07-BLAN-0009-01, Michel Magny and Nathalie Combourieu-Nebout).

\section{References}

Allevato E, Fedele F, Terrasi F et al. (2013) High-resolution archaeoenvironmental study of cultic episode at a statue-menhir Copper Age site (Ossimo Anvòia, Italian Alps). Radiocarbon 55: 49-58.

Battaglia R (1943) La palafitta del lago di Ledro nel Trentino. Memorie del Museo di Storia Naturale 7: 1-64.

Beug HJ (1964) Untersuchungen zur spätglazialen Vegetationsgeschichte im Gardaseegebiet unter besonderer Berücksichtigung der mediterranen Arten. Flora (Ankara, Turkey) 154: 401-444.

Beug HJ (2004) Leitfaden der Pollenbestimmung für Mitteleuropa und angrenzende Gebiete. München: Pfeil.

Blaauw M (2010) Methods and code for 'classical' age-modelling of radiocarbon sequences. Quaternary Geochronology 5: 512-518.

Bruno A (2012) Spears in context: Typology, life-cycles and social meanings in Bronze Age Italy. $\mathrm{PhD}$ Thesis, The University of Manchester, $679 \mathrm{pp}$.

Büntgen U, Tegel W, Nicolussi K et al. (2011) 2500 years of European climate variability and human susceptibility. Science 331: 578-582.
Carancini GL and Peroni R (1999) L'età del bronzo in Italia: per una cronologia della produzione metallurgica (Quaderni di Protostoria 2). Perugia: Ali\&no.

Carra M (2012) Per una storia della cerealicoltura in Italia settentrionale dal Neolitico all'Età del Ferro: strategie adattive e condizionamenti ambientali. $\mathrm{PhD}$ Thesis, Università di Bologna, 248 pp.

Coccolini G (2006) The Wooden artefacts of the Bronze Age lakeshore dwellings of Ledro belonging to Italian Museum collections. Journal of Wetland Archaeology 6: 127-136.

Cortesi C and Leonardi G (2002) Nuovi dati radiometrici dalla palafitta di Molina di Ledro (scavi 1980, 1983). Istituto Italiano di Preistoria e Protohistoria 33: 369-376.

Cremaschi M, Pizzi C and Valsecchi V (2006) Water management and land use in the terramare and a possible climatic cofactor in their abandonment: The case study of the terramara of Poviglio Santa Rosa (northern Italy). Quaternary International 151: 87-98.

Davis BAS, Brewer S, Stevenson AC et al. (2003) The temperature of Europe during the Holocene reconstructed from pollen data. Quaternary Science Reviews 22: 1701-1716.

Dearing JA (2006) Climate-human environment interactions: Resolving our past. Climate of the Past 2: 187-203.

Deline P and Orombelli G (2005) Glacier fluctuations in the western Alps during the Neoglacial, as indicated by the Miage morainic amphitheater (Mont Blanc massif, Italy). Boreas 34: 456-467.

De Marinis RC (1997) L'età del bronzo nella regione benacense e nella pianura padana a nord del Po. In: Bernabò Brea M, Cardarelli A, Cremaschi M et al. (eds) Le Terramare: La più antica civiltà padana. Milano: Mondadori Electa, pp. 405-422.

De Marinis RC (1999) Towards a relative and absolute chronology of the Bronze Age in northern Italy. Notizie Archeologiche Bergomensi 7: 23-100.

De Marinis RC, Ravazzi C, Arpenti E et al. (2005) Lavagnone (Desenzano del Garda): New excavations and paleoecology of a Bronze Age pile dwelling site in northern Italy. In: Della Casa P and Trachsel M (eds) WES'O4, Wetland Economies and Societies, Collectio Archaeologica, vol. 3. Zurich: Chronos, pp. 221-232.

Drysdale R, Zanchetta G, Hellstrom J et al. (2006) Late Holocene drought responsible for the collapse of Old World civilizations is recorded in an Italian cave flowstone. Geology 34: 101-104.

Egli M, Mirabella A and Sartori G (2008) The role of climate and vegetation in weathering and clay mineral formation in late Quaternary soils of the Swiss and Italian Alps. Geomorphology 102: 307-324.

Fasani L (2002) Età del bronzo, in Preistoria Veronese. In: Aspes A (ed.) Preistoria Veronese: Contributi e aggiornamenti (2a serie, Sezione Scienze dell'Uomo 5). Verona: Museo Civico di Storia Naturale, pp. 107-116.

Favilli F, Cherubini P, Collenberg M et al. (2010) Charcoal fragments of Alpine soils as an indicator of landscape evolution during the Holocene in Val di Sole (Trentino, Italy). The Holocene 20: 67-79.

Festi D, Putzer A and Öggl K (in press) Mid and late Holocene land-use changes in the Ötztal Alps, territory of the Neolithic Iceman 'Ötzi'. Quaternary International.

Filippi ML, Heiri O, Arpenti E et al. (2005) Studio paleolimnologico del Lago Nero di Cornisello (Parco Naturale Adamello-Brenta, Trentino). Studi Trentini di Scienze Naturali: Acta Geologica 82: 261-278.

Filippi ML, Heiri O, Arpenti E et al. (2007) Evoluzione paleoambientale dal Tardoglaciale a oggi ricostruita attraverso lo studio dei sedimenti del Lago di Lavarone (Altopiano 
di Folgaria e Lavarone, Trentino). Studi Trentini di Scienze Naturali: Acta Geologica 82: 279-298.

Finsinger W and Tinner W (2006) Holocene vegetation and landuse changes in response to climatic changes in the forelands of the southwestern Alps, Italy. Journal of Quaternary Science 21: 243-258.

Foley JA, DeFries R, Asner GP et al. (2005) Global consequences of land use. Science 309: 570-574.

Gobet E, Tinner W, Hochuli P et al. (2003) Middle to Late Holocene vegetation history of the Upper Engadine (Swiss Alps): The role of man and fire. Vegetation History and Archaeobotany 12: 143-163.

Gottardini E, Cristofori A, Cristofori F et al. (2004) Palynological analyses on sediments of Lake Tovel (Trentino, Italy). Studi Trentini di Scienze Naturali: Acta Biologica 81: 147-154.

Grimm E (1992-2005) Tilia (Version 2.0.2) and TiliaGraph 1.12. Springfield, IL: Research and Collection Centre, Illinois State Museum.

Heiss AG, Kofler W and Öggl K (2005) The Ulten Valley in South Tyrol, Italy: Vegetation and settlement history of the area, and macrofossil record from the Iron Age Cult Site of St. Walburg. Palyno-Bulletin 1: 63-73.

Hughes PD (2010) Little Ice Age glaciers in Balkans: Low altitude glaciation enabled by cooler temperatures and local topoclimatic controls. Earth Surface Processes and Landforms 35: 229-241.

Ivy-Ochs S, Kerschner H, Maisch M et al. (2009) Latest Pleistocene and Holocene glacier variations in the European Alps. Quaternary Science Reviews 28: 2137-2149.

Jalut G, Dedoubat JJ, Fontugne M et al. (2009) Holocene circum-Mediterranean vegetation changes: Climate forcing and human impact. Quaternary International 200: 4-18.

Joannin S, Ali AA, Ollivier V et al. (2014) Vegetation, fire and climate history of the Lesser Caucasus: A new Holocene record from Zarishat fen (Armenia). Journal of Quaternary Science 29: 70-82.

Joannin S, Brugiapaglia E, de Beaulieu JL et al. (2012) Pollenbased reconstruction of Holocene vegetation and climate in southern Italy: The case of Lago di Trifoglietti. Climate of the Past 8: 1973-1996.

Joannin S, Vannière B, Galop D et al. (2013) Climate and vegetation changes during the Lateglacial and early-middle Holocene at Lake Ledro (southern Alps, Italy). Climate of the Past 9: 913-933.

Kleinen T, Tarasov P, Brovkin V et al. (2011) Comparison of modeled and reconstructed changes in forest cover through the past 8000 years: Eurasian perspective. The Holocene 21: 723-734.

Luterbacher J, Xoplaki E, Casty C et al. (2006) Chapter 1. Mediterranean climate variability over the last centuries: A review. In: Lionello P, Malanotte-Rizzoli P and Boscolo R (eds) Mediterranean Climate Variability, vol. 4. Amsterdam: Elsevier, pp. 27-148.

Magny M, Combourieu-Nebout N, de Beaulieu JL et al. (2013) North-south palaeohydrological contrasts in the central Mediterranean during the Holocene: Tentative synthesis and working hypotheses. Climate of the Past 9: 2043-2071.

Magny M, Galop D, Bellintani P et al. (2009a) Late-Holocene climatic variability south of the Alps as recorded by lake-level fluctuations at Lake Ledro, Trentino, Italy. The Holocene 19: $575-589$.

Magny M, Joannin S, Galop D et al. (2012) Holocene palaeohydrological changes in the northern Mediterranean borderlands as reflected by the lake-level record of Lake Ledro, northeastern Italy. Quaternary Research 77: 382-396.

Magny M, Vannière B, Zanchetta G et al. (2009b) Possible complexity of the climatic event around 4300-3800 cal. BP in the central and western Mediterranean. The Holocene 19: 823-833.

Mangini A, Spötl C and Verdes P (2005) Reconstruction of temperature in the Central Alps during the past $2000 \mathrm{yr}$ from a $\delta^{18} \mathrm{O}$ stalagmite record. Earth and Planetary Science Letters 235: 741-751.

Marzatico F (2007) La frequentazione dell'ambiente montano del territorio atesino fra l'età del Bronzo e del Ferro: Alcune considerazioni sulla pastorizia transumante e 'l'economia di malga'. Preistoria Alpina 42: 163-182.

Marzatico F (2009) Le plus ancien pastoralisme en 'territoires extrèmes' des Alpes italiennes centre-orientales. Le Globe 149: 117-136.

Marzatico F, Valzolgher E and Oberrauch H (2010) Dating the later Bronze Age metal production in the south-central Alps: Some remarks on the relative and absolute chronology of the Luco/Laugen culture. In: Mining in European History and Its Impact on Environment and Human Societies: Proceedings for the 1st Mining in European History-Conference of the SFB-HiMAT (ed P Anreiter, G Goldenberg, K Hanke et al.), Innsbruck, 12-15 November 2009, pp. 129-143. Innsbruck: Innsbruck University Press.

Menotti F (2004) Living on the Lake in Prehistoric Europe: 150 Years of Lake-Dwelling Research. London: Routledge, 304 pp.

Mercuri AM, Sadori L and Blasi C (2010) Archaeobotany for cultural landscape and human impact reconstructions. Plant Biosystems 144: 860-864.

Mercuri AM, Accorsi CA, Mazzanti MB et al. (2006) Economy and environment of Bronze Age settlements - Terramaras - on the Po Plain (Northern Italy): First results from the archaeobotanical research at the Terramara di Montale. Vegetation History and Archaeobotany 16: 43-60.

Mercuri AM, Allevato E, Arobba D et al. (submitted) Pollen and macroremains from Holocene archaeological sites: a dataset for the understanding of the bio-cultural diversity of the Italian landscape. Review of Palaebotany and Palynology.

Mercuri AM, Allevato E, Arobba D et al. (submitted) Pollen and macroremains from Holocene archaeological sites: A dataset for the understanding of the bio-cultural diversity of the Italian landscape. Review of Palaebotany and Palynology.

Mercuri AM, Mazzanti M, Torri P et al. (2012) A marine/terrestrial integration for mid-late Holocene vegetation history and the development of the cultural landscape in the Po valley as a result of human impact and climate change. Vegetation History and Archaeobotany 21: 353-372.

Moe D, Fedele FG, Maude AE et al. (2007) Vegetational changes and human presence in the low-alpine and subalpine zone in Val Febbraro, upper Valle di Spluga (Italian central Alps), from the Neolithic to the Roman period. Vegetation History and Archaeobotany 16: 431-451.

Moore PD, Webb JA and Collinson ME (1991) Pollen Analysis. London: Blackwell Scientific Publications.

Nash G (2012) Replicating cultural landscapes: Interpreting rock-art in the Valcamonica, Lombardy, Italy. Landscapes 12: 1-19.

Nequirito M (2002) A norma di Regola. Le comunità di villaggio trentine dal medioevo alla fine del '700 (Quaderni 1 Servizio). Trento: Beni librari e archivistici del Trentino.

Peyron O, Magny M, Goring S et al. (2013) Contrasting patterns of climatic changes during the Holocene across the Italian Peninsula reconstructed from pollen data. Climate of the Past 9: $1233-1252$.

Pini R (2002) A high-resolution Late-Glacial - Holocene pollen diagram from Pian di Gembro (Central Alps, Northern Italy). Vegetation History and Archaeobotany 11: 251-262. 
Pinton V and Carrara N (2007) La collezione della palafitta di Ledro del Museo di Antropologia dell'Università di Padova: ricostruzione del paleoambiente. Annali dell'Università degli Studi di Ferrara - Museologia Scientifica e Naturalistica (Special Volume): 11-14.

Reille M (1992-1998) Pollen et Spores d'Europe et d'Afrique du nord. Marseille: Laboratoire de Botanique historique et Palynologie, Université d'Aix-Marseille, 520 pp.

Reimer PJ, Baillie MGL, Bard E et al. (2009) INTCAL09 and MARINE09 radiocarbon age calibration curves, 0-50,000 years cal BP. Radiocarbon 51: 1111-1150.

Rey F, Schwörer C, Gobet E et al. (2013) Climatic and human impacts on mountain vegetation at Lauenensee (Bernese Alps, Switzerland) during the last 14,000 years. The Holocene 23: $1415-1427$.

Röpke A and Krause R (2013) High montane-subalpine soils in the Montafon Valley (Austria, northern Alps) and their link to land-use, fire and settlement history. Quaternary International 308-309: 178-189.

Rottoli M and Castiglioni E (2011) Plant offerings from Roman cremations in northern Italy: A review. Vegetation History and Archaeobotany 20: 495-506.

Schmidl A, Kofler W, Oeggl-Wahlmüller N et al. (2005) Land use in the eastern Alps during the Bronze Age - An archaeobotanical case study of a hilltop settlement in the Montafon (Western Austria). Archaeometry 47: 455-470.

Segard M (2009) Les Alpes occidentales romaines. Paris: Editions Errance, 288 pp.

Simonneau A, Chapron E, Vannière B et al. (2013) Mass-movement and flood-induced deposits in Lake Ledro, southern Alps, Italy: Implications for Holocene palaeohydrology and natural hazards. Climate of the Past 9: 825-840.

Soane ID, Scolozzi R, Gretter A et al. (2012) Exploring panarchy in alpine grasslands: An application of adaptive cycle concepts to the conservation of a cultural landscape. Ecology and Society $17: 1-18$.

Tinner W, Lotter AF, Ammann B et al. (2003) Climatic change and contemporaneous land-use phases north and south of the
Alps 2300 BC to 800 AD. Quaternary Science Reviews 22: $1447-1460$.

Tinner W, van Leeuwen JFN, Colombaroli D et al. (2009) Holocene environmental and climatic changes at Gorgo Basso, a coastal lake in southern Sicily, Italy. Quaternary Science Reviews 28: 1498-1510.

Tweddle JC, Edwards KJ and Fieller NRJ (2005) Multivariate statistical and other approaches for the separation of cereal from wild Poaceae pollen using a large Holocene dataset. Vegetation History and Archaeobotany 14: 15-30.

Valsecchi V and Tinner W (2010) Vegetation responses to climatic variability in the Swiss Southern Alps during the Misox event at the early-mid Holocene transition. Journal of Quaternary Science 25: 1248-1258.

Valsecchi V, Carraro G, Conedera M et al. (2010) Late-Holocene vegetation and land-use dynamics in the Southern Alps (Switzerland) as a basis for nature protection and forest management. The Holocene 20: 483-495.

Valsecchi V, Tinner W, Finsinger W et al. (2006) Human impact during the Bronze Age on the vegetation at Lago Lucone (northern Italy). Vegetation History and Archaeobotany 15: 99-113.

Van Geel B, Buurman J and Waterbolk HT (1996) Archaeological and palaeoecological indications of an abrupt climate change in The Netherlands, and evidence for climatological teleconnections around 2650 BP. Journal of Quaternary Science 11: 451-460.

Vannière B, Magny M, Joannin S et al. (2013) Orbital changes, variation in solar activity and increased anthropogenic activities: Controls on the Holocene flood frequency in the Lake Ledro area, Northern Italy. Climate of the Past 9: 1193-1209.

Wanner H, Beer J, Buetikofer J et al. (2008) Mid- to Late Holocene climate change: An overview. Quaternary Science Reviews 27: 1791-1828.

Wirth SB, Gilli A, Simonneau A et al. (2013) A 2000 year long seasonal record of floods in the southern European Alps. Geophysical Research Letters 40: 4025-4029. 